\title{
Implementation of Law Number 14 Year of 2008 on Public Disclosure (Study Case on Information Management Officer and Documentation in Medan Municipality)
}

\author{
Asima Yanty Siahaan \\ Department of Public Administration \\ Universitas Sumatera Utara \\ Medan, Indonesia \\ asimayantysiahaan@gmail.com
}

\author{
Piki Darma Kristian Pardede \\ Department of Public Administration \\ Universitas Sumatera Utara \\ Medan, Indonesia \\ piki_pardede16@yahoo.com
}

\begin{abstract}
Public Disclosure is a condition of the formation of the government is open (open governance). Disclosure of information respecting democratic values in good governance. Where is the guarantee legal certainty which will be accepted by the public in obtaining access to information openly channeling aspirations for self-development and public scrutiny of the performance of state officials in the increased development. Birth of Act No. 14 year of 2008 on Public Information which came into force 30 April 2010 shows the government's commitment to ensure the needs of the community for information.
\end{abstract}

By using a qualitative descriptive approach this study in detail describe the process of implementing the legislation, it can be concluded that the PPID Pemko field has been implementing Law No. 14 year of 2008 on public disclosure with good but not maximum, especially in terms of providing services and public information and related to the implementation of the absence of a strong legal basis in the form of regulations mayor in regulatory and supervisory policies and lack of initiative in the use of the infrastructure for the availability of information.

It is suggested that city government PPID field proposed draft local regulations as the legal basis for guidance in the implementation of the openness of information and to improve the capability of knowledge and skills in optimizing infrastructure provision of public information services in the city of Medan.

Keywords - the implementation of law, public disclosure, ppid, the government of medan

\section{INTRODUCTION}

Public service and public information disclosure can't be separated, although it is regulated in a separate law. The state is obliged to serve every citizen to fulfill his basic rights and needs within the framework of public services. According to the Decree of the Minister of Administrative Reform No.63 / Kep / M.PAN / 7/2003 dated July 10, 2003 on General Guidelines for the Implementation of Public Service. Public Service is any service activities undertaken by the providers of public services as an effort to meet the needs of service recipients and implementing the provisions of legislation.

Currently, the implementation of public services is still faced with conditions that have not been in accordance with the needs. This is evident from the unpreparedness in responding to the transformation of dimensionless values and the impact of complex development problems. On the other hand, state organizers are still co-opted with a new-order government model that closes information for its people. Current reform demands a transparent and accountable exercise of power for the public.

Public information is absolutely essential to a society in a country because it involves what the state does to them. The right to obtain information is a right of each citizen, and public information disclosure is one of the important features of a democratic country that upholds the sovereignty of the people for the sake of good state administration.

Currently Law No. 14/2008 on KIP as far as its implementation not all institutions and public bodies in North Sumatra who understand and run the mandate of the Act Information Disclosure. Evidently, based on data released by the Central Information Commission of information disclosure conducted by the Central Government and the Ministry there are only 11 agencies from 26 agencies. This shows the low compliance of local governments in implementing Ministry of Home Affairs instructions to provide budget information openly. The USAID-supported Forum Indonesia Untuk Transparansi Anggaran (FITRA) launched the Budget Information Disclosure Index. In its Report, FITRA recorded an average score of information disclosure index of district / city government budget is only 14.1 from ideal score 100.10 Most Open Towns are a. Semarang City with score 45,53, b. Pontianak city with a score of 41.66 , c. Salatiga city with a score of 38.52, d. Kota Banda Aceh with a score of 31.97 e. Surakarta City with a score of 25.58 , f. Sabang City with a score of 24.44 g. City of Madina with score 23,89, h. Kota Pekalongan with score 21.35 , i. Singkawang city with a score of 19.73 and the last city of Binjai with a score of 17.66. This is evidence of the lack of local government that publishes 
budget documents through the website. Local governments that publish budget information are still under 25 percent (Seknas FITRA, 2015).

Law No. 14 year of 2008 on KIP as far as its implementation not all institutions and public bodies in North Sumatra who understand and run the mandate of the Act Information Disclosure. This is due to the compliance of local government to implement the mandate of Law No 14 years of 2008 very low seen from 33 districts / cities in North Sumatra, only eight districts / municipalities forming Information and Documentation Management Officials (PPID) is Medan Municipality, Siantar, Tobasa , Langkat, Karo, Dairi, Sergei and Gunung Sitoli Municipality. The remaining 25 districts / cities have not been appointed PPID.

Public information disclosure is an important discourse within the framework of excellent public services, and as a legal basis relating to the right of everyone to obtain information because the information disclosure is a means in optimizing public oversight of the state administration.

This study examines the implementation of law number 14 year of 2008 on public disclosure in Medan Municipality.

\section{LITERATURE REVIEW}

Openness is one of the requirements for the formation of democratic society. The existence of openness, people will feel to have and play an active role in every implementation of National Development.

Public Information is information generated, stored, managed, transmitted, and / or received by a Public Agency relating to the organizers and the administration of the state and / or the organizer and the operation of other Public Bodies in accordance with the Law on Public Openness or transparency means the availability of government to always provide factual information about various matters pertaining to the process of administering the government (Article 1, UU KIP No 14 Year of 2008). Information is very important for the government to exercise oversight, Conceptually the public is entitled to obtain information services related to publicly financed organizations overseen by public officials. It is the people's right to obtain information that encourages transparency of information as a form of state responsibility. Disclosure of information or guarantees of public access to information, democratic state systems and good governance are the three concepts that are interconnected with each other. Freedom of information is a spirit of democratization that offers both inherent freedom and responsibility. This freedom also breeds governability in which the state can function itself effectively and efficiently without overriding democratic principles. Given the openness in the process of organizing the state will give a double benefit of encouraging the community to participate actively in government or in the implementation of development and government policies.

\section{RESEARCH METHOD}

This study uses a descriptive qualitative research type, which describes the complete, detailed, clear and systematic and look at whether a legislation made by the Government can be run in accordance with the provisions or not. This research I will examine whether the Law Number 14 year of 2008 and in particular on the Role of public institutions of PPID can be executed in accordance with the provisions or not. While the design of this study is a case study of intensive research on a particular organization, institution or symptom with or limited but in-depth coverage area. The subject of research reflected in the focus of this study is deliberately determined, the subject will be the respondent who provided the information and information required. Key informants are in accordance with this research technique that is the Head of Communications and Information Government of Medan Municipality as Ex-Officio Chief Information Management Official and Documentation Office of Communications and Information Government of Medan. These informants are also called key informants. In addition, to enrich the information, some other sources such as academics, NGOs, and journalist will also be respondents. They are often referred to as additional informants.

\section{RESULT AND DISCUSSION}

A. Implementation of Law No. 14 of 2008 on public disclosure in Medan Municipality government.

1) Legal Basis for Implementation of Law No. 14 of 2008 on public disclosure in Medan Municipality government.

Implementation of Law Number 14 year of 2008 on Public disclosure in Medan Municipality begins with the issuance of Permendagri No. 35 year of 2010 on Guidelines for Information Management Services and documentation within the Ministry of Home Affairs and Local Government. Based on the direction of the Ministry of Home Affairs of Medan Municipality issued a Keputusan Walikota No: 482 / 091.k / 2012 about Guidelines for Appointment of Head of Communications and Infomatics Office of Medan Municipality as PPIDs Official in Medan City Government. This regulation is issued as the legal basis for the implementation of public information disclosure law, accelerating the promotion and implementation of public information disclosure so as to create a good state governance that is transparent, effective and efficient, accountable and accountable so that the realization of Good-Governance.The Mayor's Decree also regulates in more detail the mechanisms for obtaining information, position and functions of PPIDs, classifying public information, provision of public information and public information disputes.

According to Alamsah Saragih there are three basic criteria in measuring the extent of the readiness of a public body in carrying out the obligations required by Law Number 14 year of 2008 on Public Information Openness. Based on Article 7 of Law Number 14 year of 2008 in conjunction with Article 4 of Information Commission Regulation Number 1 year of 2010 concerning Standard of Public Information Service, namely:

- Public institutions have at least the obligation to establish regulations on standard operating procedures of public information services, 
- Appointing Information and Documentation Management Officer (PPIDs), and

- Periodically establish the Public Information List of all publicly-managed information.

Regarding the existence of PPID, it has been regulated in the regulation such as Law No. 14 of 2008 on Public Information Transparency Pasal 13 Paragraph 1 :

"To realize the fast, precise, and simple service of every Agency The Public appoints the Information Management and Documentation Officer."

PP no. 61 of 2010, Pasal 12 paragraph (1):

"Officials who may be appointed as PPIDs within the Public Authority Countries that are at the center and in the regions are officials who in charge of Public Information"

It is also supported by Pasal (6) and Pasal (7) of Information Commission Regulation No. 1 of 2010 on Public Information Service Standards, is :

"Pasal 6: PPIDs are responsible for the field of public information services which include the process of storing, documenting, providing and providing public information"

"Pasal 7: The PPIDs is responsible for coordinating the storage and documentation of all public information in the Public Authority."

Based on the results of research conducted it can be concluded that the Government of Medan in running the mandate of Law No. 14 years of 2008 legal defects, where in the implementation of the implementation of the principles of public information services there is no strong legal basis. Where the legal products in the form of local regulations and regulations of the mayor as a guideline of the Medan City Government in the implementation of KIP Act does not yet exist, this proves that in the implementation of public disclosure of Medan city government does not have seriousness and commitment in the implementation process of legislation. In the Mayor's Decree of Medan No. 482 / 091.K / 2012.- only regulates the mechanism for obtaining information, position and function of PPIDs, public information classification, provision of public information and public information disputes.

Should refer to the Regulation of the Minister of Home Affairs No. 35 years of 2010 on Guidelines for Management of Information Services and Documentation within the Ministry and Local Government. Medan Municipality is obliged to issue legal products in the form of local regulations to support the implementation of public information disclosure, namely Mayor Regulation.

Based on the results of the research the researchers see that there is no legal basis in regulating the implementation of information disclosure in the city of Medan. The Medan City Government has no commitment to protect the right of the people to gain access to information. It can be concluded that the absence of a strong legal foundation has not guaranteed the Medan Municipality to run the evaluation in every program maximally and serve as guidance in the implementation of public information disclosure in Medan Municipality government.

2) Standard Operational Procedure (SOP) of Public Information Service in Medan Municipality government.

To encourage the effective implementation of the Public Information Disclosure Act, every public body is mandated to develop Standard Operating Procedures (SOP) of Public Information Services which have service standards that relate to procedures and time as a standard measure for the conduct of public service and shall be obeyed by giver and recipient of information services pursuant to Law Number 14 Year 2008 on Public Information Disclosure Article 13 Paragraph 2 which reads:

"To realize the quick, precise and simple service of every Public Agency: to create and develop an information delivery system system quickly, easily and reasonably in accordance with the technical guidelines of a nationally recognized standard of Information Services."

The standard public information service as follows:

\section{a) Public Service Information Operations}

To carry out information services should be supported by the Front Office and Back Office is good.

Front Office folded:

- Direct service desk

- Desk service via media

Back Office:

- Field services and documentation information,

- Field data processing and information classification,

- The field of dispute resolution information.

\section{b) Public Information Desk}

To meet the demand for services and public information needs, information management and documentation officials through the information service desk conduct direct service and services through the media, among others, using telephone, e-mail, and website.

From the results of research and observations conducted by public service information service through announcements made Desk media services such as websites, information boards and direct service desk that applicants can come to PPID Medan Municipality to request the information by filling out the application form information. Providing public information services through ppid.pemkomedan.go.id websites whether public information such as Public Agency Profile, Program and Activity, Regulation and Access to Public Information not updated or updated can be seen from the processed table of researchers as: 
Table.1. Website PPID MedanMunicipality government

\begin{tabular}{|l|c|c|}
\hline No & Status Information & Type \\
\hline 1. & Public Agency Profile & Exist \\
\hline 2. & $\begin{array}{c}\text { Program Information and } \\
\text { Activities Public Agency }\end{array}$ & $\begin{array}{c}\text { Not Update } \\
(2015)\end{array}$ \\
\hline 3. & Financial Statements & $\begin{array}{c}\text { Not Update } \\
(2015)\end{array}$ \\
\hline 4. & $\begin{array}{c}\text { Regional Regulation and } \\
\text { Government Policy }\end{array}$ & $\begin{array}{c}\text { Not Update } \\
(2015)\end{array}$ \\
\hline 5. & Access Information & Exist \\
\hline 6. & $\begin{array}{c}\text { Performance report of Public } \\
\text { Agency }\end{array}$ & Not Update \\
\hline 7. & $\begin{array}{c}\text { Procurement of goods and } \\
\text { services pursuant to Regulation of } \\
\text { the Law }\end{array}$ & Not Update \\
\hline 8. & $\begin{array}{c}\text { Complaints procedure (request) } \\
\text { information }\end{array}$ & Exist \\
\hline
\end{tabular}

Source: Processed Researcher

The use of Billboard available at some point of Medan City is not maximal in terms of publication innovation of government policy implementation. In accordance with the SOP PPID Pemko Medan pattern of responses to the request for information is also done well that is processing the application at least within 14 working days. And the application procedure does not incriminate the applicant because the bureaucratic system is not convoluted.

Information services can be viewed through the SOP mechanism of the public information request. Some mechanisms in public information services are the application mechanism, the period of public information service, and public information infrastructure facilities.

3) Implementation of Law No. 14 Year 2008 on Public disclosure in Medan Municipality government. a) communication

The success of the policy implementation implies that the implementor knows what to do and what the group aims and targets so that the implementation can actually work and if the goals and objectives are not known then resistance will arise from the targeted group. it is seen that Law no. 14 Year of 2008 on Public disclosure has been understood by the implementing agent of the regulation well seen from the informant's understanding of the purpose of the policy, duties, functions and authority of the PPID Officials in creating a transparent and accountable government. Secretary PPIDs Pemko Medan explained that PPID Medan city always coordinate to the Mayor of Medan as Penanggug Jawab, so PPID Pemko should always report performance periodically. PPID Pemko Medan also coordinates with PPID Assistant in every SKPD in Medan City Government, but the weak commitment shown by PPID in each SKPD is seen from the lack of understanding on the content of the policy. He also added that PPID Medan City along with Provincial PPID will always coordinate in implementing Socialization in improving the performance of PPID. The researcher concludes that the implementation of the Public Information Disclosure Act in Medan City is a commitment of good policy implementing agents in understanding the main tasks and functions and supported by government policies that support the implementation of Open Governance.

b) Implementation Objectives Act No. 14 Year of 2008 About Public Disclosure.

According to George Edward III the determination of policy targets is influenced by how the implementor is able to deliver well the content and purpose of a policy. Implementation of this policy will produce output and outcome where the output is the perceived impact of policy goals from the implementation of policies and outcomes is the impact felt by those who are not targeted in this policy. Seen that the contents of the policy Act No. 14 year of 2008 on Public disclosure has been run by PPID Officials themselves seen from the services provided by PPID Pemko Medan in response to the request for information submitted by the people of Medan. From the description of the source James Ambarita the response of the petition by PPID Pemko Medan classified quickly ranged for 14 working days. PPID Pemko Medan also provides direction in the process of requesting information.

Furthermore, the problem arising from this policy objective is the request for information made by the applicant is in the application of public information Individual or legal entity (NGOs) does not have the purpose of the use of public information is clear.

c) Implementation Objectives Act No. 14 Year of 2008 About Public Disclosure.

Resources are the most important factor in the implementation of the policy to run in accordance with the objectives to be achieved. Resources can be human resources, capital resources (finansial) and supporting resources in the form of facilities. In the implementation of law no 14 year of 2018 seen that officials PPID Pemko Medan appointed in accordance with the position attached to employees and officials PPID has received training in the form of socialization Tasks and Functions PPID is often done with PPID North Sumatra Province and Information Commission of North Sumatra Province and presenting Media and NonGovernmental Organization. However, in terms of understanding PPID Pemko Medan especially PPID in each SKDP who do not fully understand the contents of the law on the type of information into public consumption.

\section{d) Facilities and Infrastructure Policy}

In the implementation of policy completeness of facilities and infrastructure policy serves as a supporter of the implementation of the implementation administration where the establishment of a good performance flow. Therefore, in the implementation of the policy, we need the facilities and infrastructures that are important for the realization of public information disclosure. However, in its implementation that in supporting the policy implication of announcement board 
facilities still not maximal in its management (updating data) is still limited to organization profile, information desk and website physically also not optimal so that the need of initiative of PPID Official in utilization of existing facilities like website utilization, information boards and Billboard existing dititik Medan City in the delivery of information, such as the need to display policy orders and lists of local regulations that have been approved so that people know how far the administration of Medan City. So it can be said that the optimization of supporting prasara means is not maximal yet.

\section{e) Disposition / Attitude.}

In the theory of policy implementation according to George Edward III the attitude or disposition of this implementor is divided into three things, namely; (a). Commitment, (b).Honesty, and (c). Democratic Attitude. Understanding this position is very important to see what the implementor must respond to. Understanding the implementation of the policy to be implemented encourages attitudes from the implementer to support or reject the implementation of the policy as well as the response given to the benchmark readiness of the implementers of their own policies to implement a policy. the implementation of the policy of public information disclosure by PPID still shows the weak disposition of implementing agent in the supervision system because the legal standing is equal to the mayor's regulation as the reference for the implementation of UU KIP currently only as the Mayor's Decree. But in the affairs of PPID Pemko Medan provide good response because members of the PPID understand the purpose of this policy and the desire of members to create a transparent government disposition PPID Pemko Medan officials in the public service very well. Responsibility in providing services to the community in the form of PPID Official's attitude that directly responds to public complaints in obtaining information.

\section{f) Bureaucratic Structure}

George Edward III explains the organization provides a simple map to show in general its activities and the distance from the peak shows its relative status. The lines between the various positions are framed to show the formal interaction applied. A clear bureaucratic structure will support the implementation of a public information disclosure policy, a structure that clearly affects the division of duties and responsibilities on each part can be properly implemented. In addition, in the implementation of a policy everyone in their respective fields are bound by the norm or value applicable work environment. Implementation of Public Information Disclosure Act by PPID Pemko Medan already has a clear organizational structure. Based on the findings and interviews with resource persons, the relationship between one work unit is very important and regulated in the existing SOP. Level hierarchy of managerial positions clear so that it looks who is responsible. The structure consists of the Information Management and Documentation Officer (PPID) of the parent and the supporting PPID residing in the SKPD. PPID is responsible to the Mayor of Medan through the Supervisor of PPID. PPID Pemko Medan also has a clear SOP where every implementation of policy performance has been set on SOP and with the number of officials that are not too much then the flow of services will tersistematis, so officials PPID should be responsive to respond to requests for information and no problem in the groove that complicated or convoluted because in the SOP is set time in response to applications ranging from 14 days of service. So it can be said that the mechanism set by PPID Pemko Medan in response to complaints of information application has been implemented well. SOPs established on the mechanism of obtaining public information that guides the PPID in carrying out its duties in implementing a fair, accountable and transparent public disclosure policy.

\section{RESULT AND DISCUSSION}

Since the beginning of the enactment of this regulation until now the implementation has been running well and in accordance with the rules and Standard Operating Procedures (SOP) that has been established. Based on the description of the results and discussions that have been described in the previous chapter then, can be drawn conclusion: Implementation of Law Number 14 Year of 2008 in Medan City Government is flawed by law where there is no legal basis or legal umbrella in the form of strong Mayor Regulation in commitment to guidance of information disclosure in Medan City. The issuance of the Decree of Mayor of Medan No: 482 / 091.k / 2012, - limited to the Appointment of Information Management and Documentation Official of Medan City Government, Medan City Government is not ready yet to implement the law. Participation and Understanding of Medan City society is low in accessing public information disclosure, there are still many people who do not yet understand the existence of Public Information Disclosure Act. Still limited to interest groups. In the case of the provision and service of Public Information the role of Information and Documentation Management Officer (PPID) of Medan City Government already has guidance, so that standardization of service according to standard operational procedure. The Need for Initiatives from PPIDs Officials of Medan City Government in Utilizing existing supporting facilities and infrastructure, such as Web and Billboard.

\section{References}

[1] Anderson, James E. 2011. Public Policymaking. Boston USA: Wadsworth.

[2] Dunn, William N. 2003, Pengantar Analisi Kebijakan Publik edisi Kedua Yogyakarta: Gadjah Mada University Press.

[3] Grindle, Merilee S. 1980, Politic and Policy Implementation in Thirth World, Pricenton: Pricenton University Press.

[4] Koalisi Untuk Kebebasan Informasi.2001.Melawan Tirani Informasi.Jakarta :Koalisi UntukKebebasan Informasi.

[5] Mihradi, R. Muhammad. 2011. Kebebasan Informasi Publik Versus Rahasia Negara. $\quad$ Bogor:Ghalia Indonesia

[6] Nugroho, Riant. 2012. Public Policy: Dinamika Kebijakan, Analisi Kebijakan dan Manajemen Kebijakan Jakarta: Penerbit PT Elex Media Komputindo.

[7] PLaCID's (Public Policy Analysis add Community Development Studies). Reformasi Birokrasi Dan Demokratisasi Kebijakan Publik. Malang: Averroes Press. 
[8] Singarimbun, Masri dan Syofian Efendi,1989. Metode Penelitian Survai. Jakarta:LP3ES.

[9] Sugiyono, 2009. Metode Penelitian Kuantitatif dan Kualitatif dan R\&D, Bandung:CV.Alfabeta.

[10] Suyanto, Bagong. 2005. Metode Penelitian Kualitatif . Bandung:CV. Alfabeta.

[11] Tangkilisan, Hessel Nogi S. MSi, 2003."Teori dan Konsep Kebijakan Publik"Yogyakarta : Lukman Offset dan YPAPI.

[12] Toha, Miftah, 2014, Birokrasi danDinamika Kekuasaan, Jakarta: Prenamedia Grup.

[13] Wiratna V. Sujarweni. 2015. Metodologi Penelitian Bisnis \& Ekonomi . Yogyakarta:Pustaka Baru Press

[14] Zuriah, N ,2006. "Metodologi Pemelitian Sosial dan Pendidikan: Teori-teori

[15] Aplikasi”, Jakarta,Bumi Aksara
[16] Undang-Undang Nomor 32 Tahun 2004 tentang Pemerintahan Daerah;

[17] Peraturan Pemerintah Nomor 79 Tahun 2005 tentang Pembinaan dan Pengawasan

[18] Penyelenggaraan Pemerintahan Daerah;

[19] Peraturan Pemerintah Nomor 61 Tahun 2010 tentang Pelaksanaan Undang-Undang

[20] Nomor 14 Tahun 2008 tentang Keterbukaan Informasi Publik;

[21] Peraturan Menteri Dalam Negeri Nomor 35 Tahun 2010 tentang Pedoman Pengelolaan

[22] Pelayanan Informasi dan Dokumentasi di Lingkungan Dalam Negeri Dan Pemerintahan Daerah;

[23] Peraturan Komisi Informasi Nomor 1 Tahun 2010 tentang Standard Layanan Informasi Publik

[24] Salinan Keputusan Walikota Medan Nomor : 482/091.K/2012.- 